\title{
BANKI CZASU W EKONOMII DZIELENIA SIĘ - PERSPEKTYWA SPOŁECZNO-EKONOMICZNA
}

\author{
Abstract \\ Time banks in sharing economy - the socio-economic perspective
}

Among new approaches to economy, sharing economy, being the one that personifies the growing importance of sharing in economy, gains probably the most attention. The aim of the article is to describe time banks as a form of sharing economy materialization perceived as a socio-economic phenomenon. Special attention is given to the time component being the accounting currency of time banks and showing at the same time the redefinition and recalculation of time in individual and societies functioning that is proceeding nowadays. The attempt to intentionally-functional explanation of the research problem is based on critical observation of socio-economical environment changes and the analysis of subject literature.

Keywords: sharing economy, time banks/time banking, time, alternative currency

\section{Streszczenie}

Spośród nowych podejść do ekonomii najwięcej uwagi poświęca się ostatnio gospodarce współdzielenia, ucieleśniającej rosnącą wagę komponentu wymiany w ekonomii. Celem artykułu jest opis banków czasu jako formy urzeczywistnienia ekonomii współdzielenia rozumianej jako zjawisko społeczno-ekonomiczne. Szczególnie skupiono się na komponencie czasu, który stanowi walutę przeliczeniową banków czasu, co odzwierciedla postępującą redefinicję i rekalkulację czasu w funkcjonowaniu jednostek i społeczeństw. Podstawę próby teleologiczno-funkcjonalnego wyjaśnienia badanego problemu stanowi krytyczna obserwacja zmian otoczenia społeczno-ekonomicznego i analiza literatury przedmiotu.

Słowa kluczowe: ekonomia dzielenia się, banki czasu, czas, waluta alternatywna

\section{Wprowadzenie}

Obszarem zainteresowania ekonomii jest gospodarowanie: produkcja, podział, wymiana i konsumpcja dóbr i usług. Dynamiczny rozwój technologii informacyjno-komunikacyjnych obalił prymat produkcji - oraz posiadania: wzrosło 
znaczenie zasobów niematerialnych - i dostępu do (użytkowania) dóbr. Procesy te leżą u podstaw nowych podejść do ekonomii, z których chyba najwięcej uwagi poświęca się ostatnio gospodarce współdzielenia ${ }^{1}$, co odzwierciedla rosnącą wagę komponentu wymiany w ekonomii: „rozpoczyna się epoka kooperacji i dzielenia się" [Bauman i in., 2017: 122]. Ewidentnie następuje zmiana paradygmatu ekonomii/gospodarowania (tabela 1).

Tabela 1

Zmiana paradygmatu ekonomii/gospodarowania

\begin{tabular}{|l|l|}
\hline \multicolumn{1}{|c|}{ AKCJA: ekonomia neoliberalna } & \multicolumn{1}{c|}{ REAKCJA: ,nowa ekonomia” } \\
\hline prymat wlasności & $\begin{array}{l}\text { prymat dostępu/wolności od posiadania, np.: } \\
\text { Mark Boyle, The Moneyless Manifesto (2012) } \\
\text { ekonomia współdzielenia } \\
\text { ekonomia dostępu } \\
\text { ekonomia na żądanie }\end{array}$ \\
\hline prymat wlasności indywidualnej & gospodarka wspólnego dobra \\
\hline prymat produkcji & $\begin{array}{l}\text { prymat wymiany/dostępu, np.: } \\
\text { ekonomia współdzielenia } \\
\text { darmonomia } \\
\text { ekonomia wdzięczności }\end{array}$ \\
\hline prymat pracy dla zysku & prymat WLB (work-life balance) \\
\hline prymat znaczenia jednostki gospodarującej & $\begin{array}{l}\text { prymat znaczenia sieci relacji w gospodarowaniu } \\
\text { homo reciprocans (wzajemność i altruizm) } \\
\text { homo contractor (kooperencja, różnorodność) }\end{array}$ \\
\hline
\end{tabular}

Źródło: opracowanie własne.

Choć przedstawione w tabeli 1 „,nowe ekonomie” dopiero się konstytuują i niekoniecznie osiągną stan dojrzałości, legitymujący nazwę „ekonomia”, niemniej en bloc wskazują na coraz powszechniejszą krytykę i odrzucanie założeń ekonomii głównego nurtu - a przede wszystkim niezgodę na wizję świata homo oeconomicusa [szerzej: Jamka, 2017].

Celem artykułu jest opis banków czasu jako formy urzeczywistnienia ekonomii współdzielenia rozumianej jako zjawisko społeczno-ekonomiczne. Wywód skoncentrowany został wokół komponentu czasu. Współcześnie bowiem postępuje redefinicja jego roli i znaczenia w funkcjonowaniu jednostek i społeczeństw, co znalazło wyraz m.in. w obserwowanym renesansie banków czasu, w których właśnie czas stanowi walutę przeliczeniową. Próbę teleologiczno-funkcjonalnego wyjaśnienia badanego problemu oparto na analizie literatury przedmiotu, w tym międzynarodowych i krajowych raportów z adekwatnych badań (z zakresu

${ }^{1} \mathrm{~W}$ artykule terminy „ekonomia/gospodarka współdzielenia” oraz „ekonomia dzielenia się” stosowane są zamiennie - jako odpowiednik sharing economy. 
ekonomii współdzielenia, zarządzania czasem i banków czasu) oraz na krytycznej obserwacji zmian otoczenia społeczno-ekonomicznego.

\section{Ekonomia dzielenia się — istota a cele działań}

We wstępie do raportu PwC (Wspót)dziel i rzqdź! Twój nowy model biznesowy jeszcze nie istnieje darmo szukać definicji ekonomii współdzielenia: treść specjalnie wyeksponowanego w nim fragmentu podkreśla jedynie, że ,to jedno z najbardziej zdumiewających i skłaniających do refleksji zjawisk, z jakim mamy do czynienia we współczesnej gospodarce" [PwC, 2016: 3].

Według autorów raportu Ekonomia wspótpracy w Polsce 2016 [Sokołowski i in., 2016: 5] ekonomia współdzielenia jest częścią szerszego zjawiska ekonomii współpracy - całkowicie się w niej zawiera. Ekonomia współpracy zostaje zdefiniowana jako ,gospodarka zbudowana na rozproszonych sieciach połączonych ze sobą jednostek i społeczności [...], w których ludzie mogą bezpośrednio wymieniać się dobrami i usługami z pominięciem firm oraz pośredników; [...] jest to zmiana modelu z «jeden-do-wielu» na model «wielu-do-wielu»" [Sokołowski i in., 2016: 10]. Firmy w ekonomii współpracy stają się ,platformami/społecznościami/sposobami organizacji, dzięki którym to ludzie wytwarzają produkty i usługi, dystrybuują je i dodatkowo wchodzą ze sobą w interakcję. Zacierają się tym samym granice pomiędzy producentami a klientami. Społeczności stają się firmami, a firmy - społecznościami" [Sokołowski i in., 2016: 10].

Jak słusznie stwierdzają autorzy cytowanego raportu, problemy definicyjne są następstwem różnorodnych perspektyw postrzegania zjawiska. Ujmuje się je jako model ekonomiczny, model biznesowy, hybrydowy model rynkowy, styl życia, kultury czy narracji, stosuje się także szereg równolegle funkcjonujących nazw, eksponujących wybrane aspekty nowych trendów: ekonomia współpracy (collaborative economy), ekonomia (współ)dzielenia (sharing economy), ekonomia dostępu (on-demand economy, ekonomia na żądanie), ekonomia „otwartego dostępu" (open source economy) itd.

Na przykład Rachel Botsman i Roo Rogers [2010], autorzy prekursorskiej książki na temat ekonomii współpracy i dzielenia się, proponują podział na:

- collaborative consumption, będącą de facto ekonomią dostępu, w której nadrzędny jest właśnie dostęp do użytkowania dobra czy usługi;

- collaborative economy, czyli gospodarowanie oparte na zinstytucjonalizowanych lub scentralizowanych sieciach łączących ludzi i społeczności, co w konsekwencji reorganizuje dotychczasowe, biznesowe modele produkcji, konsumpcji, finansowania i nauczania;

- sharing economy, która odnosi się do niewykorzystanych zasobów: materialnych (ziemi, pomieszczeń, środków transportu etc.), finansowych i niematerialnych (umiejętności, wiedzy, czasu etc.).

Problemów definicyjnych nie ułatwiają kwestie językowe: collaborative consumption, jako forma ekonomii dzielenia się, tłumaczona jest jako „wspólna 
konsumpcja” czy „współdzielona konsumpcja”, co w zasadzie kastruje znaczeniowo termin oryginalny, angielskojęzyczny, pozbawiając go kluczowego zakotwiczenia w pracy (collaboration - współpraca). Dodatkowo pojęcia ekonomii współpracy i ekonomii dzielenia się potocznie używane są wymiennie - jako synonimy.

Być może więc, tak jak w przypadku kapitału społecznego, na którego temat panuje o wiele powszechniejsza zgoda co do tego, co robi, niż co do tego, czym jest [Hobbs, 2000], także w odniesieniu do ekonomii dzielenia się należy skupić się na jej formach i obszarach działań.

Według Ivany Pais i Giancarla Provasiego [2015] w ramach ekonomii współdzielenia można wyróżnić sześć klas praktyk:

- ekonomię wynajmu (rental economy) - od firm posiadających wyłączność na własność wynajmowanych dóbr (np. ZipCar);

- peer-to-peer economy - gdy niewykorzystane dobra są oferowane do wynajmu przez ich bezpośrednich właścicieli - za pomocą specjalnych platform (np. AirBnB);

- ekonomię na żądanie (on-demand economy) - gdy wynajem dotyczy usług świadczonych przez profesjonalistów i osoby prywatne (np. Uber);

- banki czasu i inne bezgotówkowe (barterowe lub oparte na pieniądzu alternatywnym) lokalne systemy wymiany;

- wolne oprogramowanie (FLOSS - free / libre open source software) (np. Linux);

- crowdfunding i pożyczki społecznościowe (np. Kickstarter).

Wydaje się, że główną przyczyną trudności definicyjnych związanych z ekonomią współdzielenia są rozbieżne kierunki celu podejmowanych działań: od celu stricte społecznego do stricte ekonomicznego (rysunek 1). Przy ekonomicznym krańcu ukazanego na rysunku wektora celu znajdują się firmy, których wyłącznym bądź dominującym celem jest zysk (np. Veturilo), aczkolwiek mogą w ten sposób przy okazji realizować cele społeczne (np. podnoszenie zdrowotności mieszkańców) czy ekologiczne (np. zmniejszanie poziomu spalin), które w sprzężeniu zwrotnym przynoszą firmie dalsze korzyści ekonomiczne (np. umowy zawierane z władzami miast na preferencyjnych warunkach). Przy krańcu społecznym znajdują się (najczęściej) jednostki, które dzięki różnym formom sieci relacji (realnych, ale głównie wirtualnych) udostępniają innym swoje niewykorzystane zasoby (materialne lub niematerialne): oddają je nieodpłatnie w dobre ręce (np. na platformie Gumtree), wymieniają się nimi w ramach barteru (np. wymiany ubranek dla dzieci, książek czy zabawek w lokalnych klubokawiarniach - często w formule ,zabierasz tyle, ile przyniosłeś”) bądź świadczą usługi (np. przez banki czasu). Celem pierwotnym nie jest tu zysk, choć rezultatem udostępnienia/wymiany mogą być korzyści materialne (też finansowe), np. świeżo wydana płyta i darmowe zaproszenia na koncert promocyjny zespołu wspartego $\mathrm{w}$ ramach crowdfundingu czy pieniądze alternatywne, umożliwiające pozyskanie innych towarów lub usług, np. dwie lekcje języka francuskiego za tort imieninowy. Wydaje się więc oczywiste, że tak różnorodnych działań nie da się precyzyjnie ująć w jednej definicji, albowiem diametralnie różne są motywy ich podejmowania, wyrastające z odmiennych potrzeb. Stanowi to pierwotną przyczynę nieporozumień, a wręcz 
sprzeczności związanych z opisem zjawiska ekonomii współdzielenia i dyskusji na jego temat. Russell Belk [2014] relacje biznesowe „przebrane” za wymianę społeczną nazywa wprost pseudo-sharing, choć od razu dodaje, że nie oznacza to, iż są niemile widziane czy nieprzyjazne dla środowiska.

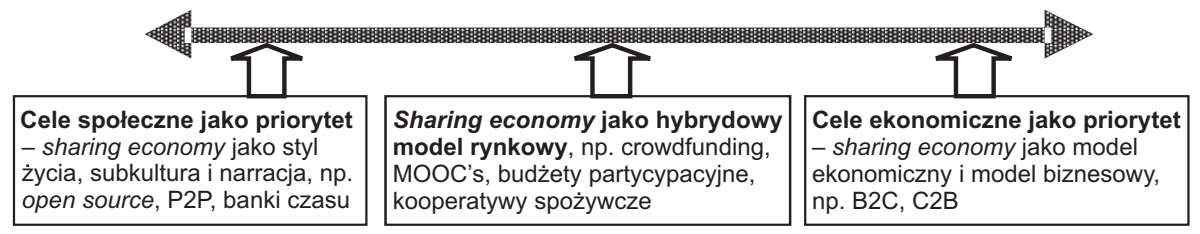

Rysunek 1. Cele działań w ekonomii współdzielenia

Źródło: opracowanie własne.

Ekonomia dzielenia się jest więc zjawiskiem istotnie niejednorodnym, opartym jednak na wspólnym kryterium kapitału społecznego. Choć w różnym natężeniu, niemniej w każdej charakterystycznej dla sharing economy formie gospodarowania stanowi on rdzeń podejmowanych działań. Według amerykańskiego raportu PwC The Sharing Economy 69\% respondentów stwierdziło, że nie ufa firmom z sektora ekonomii współdzielenia, dopóki nie zostaną im polecone przez zaufaną osobę [za: PwC, 2016: 9].

\section{Czas jako waluta alternatywna: potrzeba rekalkulacji}

John Kenneth Galbraith w podsumowaniu swojej książki Pieniadz. Pochodzenie i losy formułuje sześć imperatywów, które będą kształtować/regulować politykę pieniężną, a więc i politykę gospodarczą, w niedalekiej przyszłości, czyli w obecnej współczesności (wydanie oryginalne - 1975). Galbraith zaczyna od stwierdzenia o ,uporczywej nieskuteczności polityki pieniężnej oraz rozczarowaniach i niebezpieczeństwach płynących z oparcia się na niej” [Galbraith, 2011: 323]. Odejście od ceny (wyrażonej w pieniądzu) odzwierciedlającej wartość użytkową do ceny (nadal w pieniądzu) ukazującej wartość wymienną (dzięki czemu T-shirt na bazarze kosztuje $10 \mathrm{zl}$, a designerski - $3000 \mathrm{zl}$ - mimo podobnej wartości użytkowej) stworzyło żyzny grunt dla finansjalizacji gospodarki, a równocześnie utrudniło zaspokajanie innych potrzeb związanych z procesami wymiany, takich jak rozwój relacji sąsiedzkich i lokalnych społeczności czy potrzeby namacalności wartości. Potrzebom niezaspokojonym przez oficjalny system pieniężny mogą zaradzić waluty alternatywne:

- społeczne - oparte na wzajemnym kredycie/zaufaniu oraz na czasie (banki czasu),

- wirtualne - np. w grach komputerowych,

- komercyjne, z których najbardziej rozwinięty jest bitcoin [Sobiecki, 2014]. 
W związku z podjętym tematem poniżej uwaga zostanie skupiona na elemencie czasu.

Zainteresowanie współczesnej ekonomii koncentruje się przede wszystkim na czasie wolnym [por. Sztaba, 2007]: to część doby (i jej przeliczników), która pozostaje do dyspozycji po odliczeniu czasu przeznaczonego na działalność zarobkową, edukację (czyli prekarierę zawodową) oraz prace domowe i czynności fizjologiczne, umożliwiające regenerację własnych zasobów/kapitału ludzkiego². Jest to jedyna pozostała ludziom część czasu, która nie została (jeszcze w pełni) podporządkowana imperatywowi produktywności. Co ciekawe (bo sprzeczne z intuicyjnym postrzeganiem życia zakonnego jako kontemplacyjnego), prekursorami potrzeby punktualności, skutkującej rozwojem narzędzi pomiaru czasu, czyli zegarów, byli benedyktyni, którym ich założyciel w VI wieku nakazał odprawiać siedem mszy świętych w określonych porach dnia [Carr, 2013: 58]. Nieco upraszczając, można powiedzieć, że w rezultacie sprzężenia zwrotnego rozwoju czasomierzy i organizacji czasu powstała naukowa organizacja pracy, której nadrzędnym celem jest maksymalizacja produktywności każdej, nawet najmniejszej jednostki czasu. Wraz z rozwojem społeczeństwa przemysłowego skrupulatna strukturyzacja czasu stała się nakazem i koniecznością. W społeczeństwie pokapitalistycznym postawa zaangażowania się w jakąkolwiek aktywność zdominowała też życie prywatne. Obecnie różnymi aspektami życia codziennego „zarządza się jak rzadkimi zasobami, szukając możliwości odpowiedzialnej maksymalizacji tam, gdzie to jest możliwe”, albowiem jako ,przedsiębiorcy samych siebie” uznajemy „relacje z innymi ludźmi za narzędzie do osiągania potencjalnych korzyści, a własne ciało za przedmiot koniecznych inwestycji i samozarządzania" [Barszczewski, 2016: 147 i 119].

Ponieważ każdej akcji towarzyszy reakcja, w turboświecie, który charakteryzuje „pułapka przyspieszenia” - czyli nieustanne podkręcanie tempa pracy i przyjmowania na siebie coraz większej liczby zadań $\mathrm{w}$ - błędnym! - oczekiwaniu ponadprzeciętnych wyników skutkujące za to wypaleniem pracowników, zmniejszającym ich zaangażowanie i produktywność [Menges, Bruch, 2010] - atrakcyjności biznesowej zaczynają nabierać koncepcje zarządzania zrównoważonego, partycypacyjnego, opartego na samozarządzaniu i samoorganizacji [por. Kostera, 2014], np. w postaci „turkusowych” organizacji [Laloux, 2015] czy przedsiębiorczości społecznej [zob. np. Yunus, 2011]. Z kolei w życiu prywatnym, realizowanym w czasie wolnym, ale nie tylko, uwolnienie od życia w pośpiechu postuluje m.in. ruch slow, który rozwija się w różnych obszarach aktywności ludzkich: jedzenia (slow food), organizacji i wystroju przestrzeni (slow design), turystyki (slow travelling), a nawet szkolnictwa (slow schooling). Nacisk kładziony jest na świadome, pozbawione pośpiechu i wykorzystujące lokalne zasoby pogłębione i zindywidualizowane przeżywanie tych aktywności jako inspirujących i rozwijających doświadczeń. Najważniejszym wyzwaniem naszych czasów jest więc „odśpieszanie”, gdyż „turbożycie” jest gospodarką rabunkową naszych możliwości

\footnotetext{
${ }^{2}$ Na temat czynnika ludzkiego jako zasobu czy kapitału - por. Jamka, 2011.
} 
przystosowawczych (somatycznych, psychicznych i intelektualnych) do otoczenia. A skoro postępu zahamować nie sposób, należy przynajmniej podjąć próbę jego rozsądnego kontrolowania, co wymaga uprzedniego przywrócenia czasowi należytej wartości przez docenienie jego wagi w kształtowaniu teraźniejszości i przyszłości [por. Sztumski, 2010].

Wykorzystanie czasu jest we współczesnym świecie kardynalnym problemem decyzyjnym (,„zas to pieniądz”). Problem polega jednak na tym, że większość aktywności ukierunkowanych jest na ilościową i jakościową intensyfikację działań produktywnych (co wywołuje opór w postaci ruchu slow i postulatów „odśpieszania”). Jednak choć dążymy do maksymalizacji produktywności czasu tych, którzy pracują (zawodowo), i próbujemy zaszczepić dyscyplinę produktywności czasowi wolnemu, akceptujemy zarazem straty czasu/jego marnotrawstwo np. z powodu długich przejazdów do pracy czy kolejek w bankach, przychodniach itd. Ladislau Dowbor, brazylijski ekonomista polskiego pochodzenia, zwraca więc uwagę na potrzebę rekalkulacji wykorzystania czasu. Ilustruje to na przykładzie miasta São Paulo, którego PKB wynosi 320 mld reali na 11 mln mieszkańców, co daje wyliczeniową wartość godziny czasu mieszkańca $-3,30$ reala. Jeśli więc czynny zawodowo mieszkaniec tego miasta traci na przejazdy 2 godziny 40 minut, to koszt straconego z tego tytułu czasu wynosi ogółem 52,8 mln reali dziennie [Dowbor, 2017: 75-76]; przemnożony przez miesiące i lata daje zupełnie inną kalkulację kosztów działań alternatywnych, takich jak budowa (drogiego) metra czy niepriorytetowe inwestycje w doskonalenie transportu naziemnego itd. Jak sam autor zastrzega, metodologia takich wyliczeń wymaga dopracowania, niemniej „rachunkowość straconych godzin" jest niezbędna dla zrównoważenia gospodarki i podniesienia jakości życia.

Z powyższego wynika, że wyzwaniem współczesnego „turboświata” w „pułapce przyśpieszenia" jest reengineering i rekalkulacja czasu: zwrot od podejścia funkcjonalnego, związanego z pełnionymi funkcjami i wykonywanymi zadaniami (praca, nauka, czas wolny etc.), nastawionego na maksymalizację produktywności wszystkich funkcji, do podejścia nastawionego na procesy zaspokajania potrzeb (np. jedzenie, uczenie się języków, czytanie, reperowanie sprzętu AGD) i upraszczania dróg ich realizacji. Zamiast pracować, by zarobić pieniądze (a taka możliwość w nazbyt wielu środowiskach, szczególnie przy niepełnej dyspozycyjności czasowej, bywa dobrem rzadkim), dzięki którym będzie można kupić potrzebną usługę/dobro, można wymieniać usługi za usługi, stosując pieniądz alternatywny w formie czasu, by uniknąć ograniczeń barteru. Dodatkowo obniża to znacząco koszty transakcyjne o koszty pośredników instytucjonalnych.

\section{Banki czasu - redefinicja zaspokajania potrzeb społeczno-ekonomicznych}

Banki czasu to inicjatywy społeczności, najczęściej lokalnych, oparte na bezgotówkowej wymianie świadczonych usług przez jej uczestników. W bankach czasu zasadniczo nie ma wyceny usług - jednostką wartości jest czas wykonania 
usługi, który może być zapośredniczony przez zakumulowane kredyty czasowe/usługowe lub dolary czasowe, np. LETS (Local Exchange and Trade System z Kanady) czy SEL (Système d'Echange Local we Francji), bądź funkcjonować tylko w formie zapisów na indywidualnych kontach, prowadzonych przez koordynatora banku.

Korzenie banków czasu sięgają XIX wieku, gdy Robert Owen, walijski socjalista utopijny i pionier ruchu spółdzielczego, próbował wprowadzić w życie koncepcję pieniądza pracy, opierającego się na uznaniu pracy za podstawę wszelkiej wartości: wytwórcy za swoją pracę otrzymywaliby „bony pracy”, będące przekazami na ekwiwalent w innych towarach [Encyklopedia PWN]. W historii współczesnej prekursorką banków czasu jest Teruko Mizushima, która w 1973 roku w Osace (Japonia) założyła sieć gospodyń domowych Volunteer Labour Bank (Ochotniczy Bank Pracy). Jej inicjatywa oparta była na wieloletnich przemyśleniach dotyczących życia kobiet (matek, gospodyń domowych), które po okresach bardzo wymagających „energetycznie” (jak czas wychowywania niemowląt i małych dzieci) przeżywają okresy „nadwyżek energetycznych” (gdy dzieci idą do szkoły), które to nadwyżki mogą być przekazane potrzebującym i „odebrane” np. w starszym wieku albo być formą spłaty wcześniej zaciągniętego „kredytu” [Lebra, 1984].

Największym popularyzatorem idei banków czasu stał się jednak Edgar Cahn, twórca koncepcji „dolarów czasu” (time dollars). Do refleksji będącej dla niego inspiracją skłonił go przebyty atak serca, który mu uświadomił, jak łatwo każda osoba, nawet taka jak on sam - prawnik piszący przemówienia dla Roberta Kennedy’ego - może stać się zależna od innych ludzi/lokalnej społeczności: warto więc dawać, by móc brać [Cahn, 2004]. Choć więc priorytetem banków czasu jest zaspokajanie potrzeb ekonomicznych ich członków, to inspiracja ich powstawania jest zawsze społeczna - wynika z relacyjnego postrzegania życia człowieka i celów jego gospodarowania.

W Polsce pierwsze banki czasu pojawiły się w 2004 roku. Jadwiga i Piotr Magnuszewscy z Trzebnicy, matematyczka i fizyk z Politechniki Wrocławskiej, zaczęli popularyzować znaleziony w internecie pomysł [Augustyn, 2004]. Trafili na dobry czas, gdyż wraz z wejściem do Unii Europejskiej pojawił się dostęp do funduszy unijnych, co umożliwiło przeprowadzenie wstępnych szkoleń, przygotowanie materiałów promocyjnych, opłacenie pracy koordynatorów i biurowych kosztów działalności - w rezultacie banki czasu w Polsce zaczęły się rozwijać. W 2009 roku w kraju działało ok. 20 banków czasu [Bielski, 2010: 371].

Ponieważ wraz z zakończeniem niektórych projektów (a właściwie brakiem dalszego finansowania) część banków czasu zawiesiła działalność, a powstające nowe, jako inicjatywy nieformalne, występują pod różnymi formami i nazwami, trudno ustalić liczbę faktycznie funkcjonujących banków czasu w Polsce. Inicjatyw opartych na charakterystycznych dla nich założeniach jest prawdopodobnie znacznie więcej, niż wynikałoby to z przeglądu literatury przedmiotu i stron internetowych poszczególnych banków. Wydają się to sugerować wyniki badania przeprowadzonego przez Dorotę Nowalską-Kapuścik w „,dzielnicach biedy” Sosnowca i Świętochłowic. Wielu z jej respondentów nazwa „bank czasu” była obca, 
ale po wyjaśnieniu zasad ich funkcjonowania zaskoczeni stwierdzali, że „,przecież my to tu mamy", a nieformalna inicjatorka badanej samopomocy sąsiedzkiej z Milowic uznała, że wzorowała się na bankach czasu, ale

[...] my to tak tutaj po prostu, bez tej otoczki [...]. Po prostu ci, którzy chcą i coś mogą zaoferować, robią to, a w zamian dostają to, czego nie potrafią. [...] Ja np. lubię i umiem piec chleb. Piekę więc chleb dla dwóch sąsiadek, a one mi się odwdzięczają. Jedna umie angielski, więc uczy moją Paulinkę, druga przywozi jajka ze wsi, takie „prosto od kury” [za: Nowalska-Kapuścik, 2017: 38].

Banki czasu są kwintesencją zmieniającego się paradygmatu ekonomii (por. tabela 1) i ekonomii dzielenia się: wychodzą od redefinicji i rekalkulacji czasu. Rdzeniem ich działalności jest zaspokojenie potrzeb ekonomicznych i społecznych dzięki wymianie usług w sieciach relacji społecznych. Wykorzystując własne umiejętności (i doskonaląc je w działaniu) uczestnicy banków czasu trenują swoje zdolności twórcze, a zainteresowanie odbiorców wzmacnia ich poczucie wartości, podkopane niemożnością czy nieumiejętnością zarabiania pieniędzy, będącego kluczowym wyznacznikiem sukcesu życiowego jednostki w ekonomii neoliberalnej. Przy okazji skutkuje to odradzaniem się rzemiosła, deprecjonowanego od czasów rewolucji przemysłowej. Banki czasu przynoszą korzyści społecznościom lokalnym - rozwijająje i integrują. Są innowacją społeczną, budującą i rozwijającą nowe rynki [Caulier-Grice i in., 2012: 25] przez aktywizację osób wykluczonych bądź biernych oraz ich zasobów materialnych i niematerialnych. Ich utworzenie jest stosunkowo łatwe do realizacji (bądź przedstawienia sponsorowi), nie ma w nich wielu niejasności prawnych, a dokonywana w ich ramach wymiana - jako bezgotówkowa - jest nieopodatkowana. Pomimo swojego alternatywnego wobec ekonomii głównego nurtu charakteru zaspokajania potrzeb ekonomicznych nie kojarzą się z nierealną utopią (jak wspomniane „bony pracy”, zwane też „notami pracy"), niebezpiecznym eksperymentem gospodarczym lub z rewolucją dążącą do obalania systemu walutowego [por. Żwawa, 2008], bo są uaktualnioną, rozszerzoną wersją odwiecznej samopomocy sąsiedzkiej.

Choć banki czasu z założenia są inicjatywą nieformalną, z analizy SWOT [Pełka, 2012] wynika, że ich największe zagrożenie ma charakter instytucjonalny. Ciągłość ich funkcjonowania jest bowiem uzależniona od stabilności finansowania (w sumie niewielkiego: koordynator plus platforma komunikacyjna). Dlatego projekty zakładania banków czasu (np. dzięki grantom unijnym) - a więc forma z założenia zamknięta w czasie - kończą się zaniechaniem bądź zawieszeniem działalności, czyli zmarnotrawieniem zainwestowanych środków, ponowną dezintegracją społeczności i obniżeniem poziomu zaspokojenia jej potrzeb. Rozwój banków czasu, ich trwanie wymagają więc wsparcia ze strony jednostek samorządu terytorialnego i uwzględnienia ich działalności w ramach polityki społecznej regionu. 


\section{Zakończenie}

Istota konstrukcji i celów funkcjonowania banków czasu jest prosta i co do zasady niezmienna: są platformą (metaforyczną lub internetową) umożliwiającą wymianę usług zaspokajających potrzeby ekonomiczno-społeczne uczestników w ramach rzeczywistej lub wirtualnej sieci społecznej. Ponieważ ich walutą przeliczeniową jest czas poświęcony na wykonanie pracy, oprócz kwestii bazowej zaspokajania potrzeb, zarazem przywracają ekonomicznym stosunkom wymiany realne podstawy, oparte na prostym kryterium porównania wydatkowanej pracy, tj. czasie jej trwania. Jest to spójne z rozwijającymi się od czasu kryzysu naftowego lat 70. XX wieku i raportu Klubu Rzymskiego Granice wzrostu [Meadows i in.,1973] koncepcjami zrównoważonego rozwoju, społecznej odpowiedzialności przedsiębiorstw, kapitału społecznego, ruchami slow czy obecnie z ekonomiami alternatywnymi wobec ekonomii głównego nurtu, eksponującymi społeczny, relacyjny charakter stosunków wymiany międzyludzkiej i postulującymi powrót do zaspokajania potrzeb zamiast niemożliwego do zaspokojenia, bo podlegającego ciągłej stymulacji, dążenia do pozyskiwania kolejnych wersji i odmian dóbr i usług. Historia potwierdza pożytek z istnienia, liczne zalety i nieliczne bariery funkcjonowania banków czasu. Tym samym zasługują one na uwagę i wsparcie jednostek samorządu terytorialnego w ramach polityki społecznej regionu.

\section{Bibliografia}

Augustyn A. (2004), Powstaje bank czasu, „Gazeta Wyborcza. Wiadomości z Wrocławia”, 26.07, http://wroclaw.wyborcza.pl/wroclaw/1,35771,2199252.html [dostęp: 6.10.2017].

Barszczewski J.P. (2016), Przymus kreatywności jako źródło cierpień. Życie i praca w obliczu neoliberalnej polityki zarzqdzania, Wydawnictwo Naukowe Katedra, Gdańsk.

Bauman Z., Bauman I., Kociatkiewicz J., Kostera M. (2017), Zarzqdzanie w plynnej nowoczesności, [tłum. A. Rasmus-Zgorzelska], Fundacja Nowej Kultury Bęc Zmiana, Warszawa.

Belk R. (2014), Sharing Versus Pseudo-Sharing in Web 2.0, „Anthropologist”, 18(1), 7-23; http://krepublishers.com/02-Journals/T-Anth/Anth-18-0-000-14-Web/Anth-18-1-000-14Abst-PDF/T-ANTH-18-1-007-14-1106-Belk-Russ/T-ANTH-18-1-007-14-1106-Belk-RussTx[2].pdf [dostęp: 6.10.2017].

Bielski P. (2010), Sieciowe działania obywatelskie [w:] J. Kronenberg, T. Bergier (red.), Wyzwania zrównoważonego rozwoju w Polsce (s. 368-387), Fundacja Sendzimira, Kraków.

Botsman R., Rogers R. (2010), What's Mine is Yours: The Rise of Collaborative Consumption, HarpersCollins Publishers, New York.

Cahn E.S. (2004), No More Throw-Away People: The Co-Production Imperative, Essential Books, Washington D.C. 
Carr N. (2013), Ptytki umyst. Jak Internet wpływa na nasz mózg, [tłum. K. Rojek], Helion, Gliwice.

Caulier-Grice J., Davies A., Patrick R., Norman W. (2012), Defining Social Innovation. Part 1, Tepsie Project, European Commission, Brussels; http://siresearch.eu/sites/default/files/1.1\%20Part\%201\%20-\%20defining\%20social\%20innovation_0.pdf [dostęp: 6.10.2017].

Dowbor L. (2017), Co to za gra? Nowe podejścia do ekonomii, Instytut Wydawniczy Książka i Prasa, Warszawa.

Encyklopedia PWN, https:/encyklopedia.pwn.pl/ [dostęp: 6.10.2017].

Galbraith J.K. (2011), Pieniqdz. Pochodzenie i losy, [tłum. S. Rączkowski], Polskie Towarzystwo Ekonomiczne, Warszawa.

Hobbs G. (2000), What is Social Capital? A Brief Literature Overview, Economic and Social Research Foundation, June, http://www.caledonia.org.uk/papers/hobbs.pdf [dostęp: 6.10.2017].

Jamka B. (2011), Czynnik ludzki we współczesnym przedsiębiorstwie: zasób czy kapitat? Od zarzqdzania kompetencjami do zarzqdzania różnorodnościq, Wolters Kluwer Polska, Warszawa.

Jamka B. (2017), Razem. Ku zmianie paradygmatu gospodarowania, Wydawnictwo Akademickie Sedno, Warszawa.

Kostera M. (2014), Occupy Management! Inspirations and Ideas for Self-Organization and Self-Management, Routledge, Oxford.

Laloux F. (2015), Pracować inaczej. Nowatorski model organizacji inspirowany kolejnym etapem rozwoju ludzkiej świadomości, [tłum. M. Konieczniak], Wydawnictwo Studio Emka, Warszawa.

Lebra T.S. (1984), Japaneese Women: Constraint and Fulfilment, University of Hawai Press, Honolulu.

Meadows D.H., Meadows D.L., Randers J., Behrens III W.W. (1973), Granice wzrostu, tłum. W. Rączkowska, S. Rączkowski, Państwowe Wydawnictwo Ekonomiczne, Warszawa.

Menges J.I., Bruch H. (2010), The Acceleration Trap, „Harvard Business Review”, 4(88), 80-86.

Nowalska-Kapuścik D. (2017), Banki czasu w ,dzielnicach biedy” jako przykład innowacyjnych wzorów konsumowania [w:] D. Nowalska-Kapuścik (red.), Technologia jako inspiracja dla interdyscyplinarnych badań naukowych, Wydawnictwo Internetowe e-bookowo, https://books.google.pl/ [dostęp: 6.10.2017].

Pais I., Provasi G. (2015), Sharing Economy: A Step Toward the Re-Embeddedness of the Economy?, „Stato e Mercato”, 3(105), 347-378.

Pełka W. (2012), Rola „, banków czasu” w rozwoju wspólnot lokalnych, „Polityka Społeczna”, 39(3), 15-19.

PwC (2016), (Wspót)dziel i rządź! Twój nowy model biznesowy jeszcze nie istnieje, PwC, Warszawa.

Sobiecki G. (2014), Walut światy równoległe, „Kwartalnik Nauk o Przedsiębiorstwie”, 4(33), 5-17.

Sokołowski D., Starzyński S., Rok B., Zgiep Ł. (2016), Raport. Ekonomia współpracy w Polsce 2016, Społeczność Ekonomia Współpracy, Warszawa.

Sztaba S. (red.) (2007), Ekonomia od A do Z. Encyklopedia podręczna, Wydawnictwa Akademickie i Profesjonalne, Warszawa. 
Sztumski W. (2010), Turboświat, pułapka przyspieszenia i ekologia czasu [w:] K. Popiołek, A. Chudzicka-Czupała (red.), Czas w życiu człowieka (s. 23-37), Wydawnictwo Uniwersytetu Śląskiego, Katowice.

Yunus M. (2011), Przedsiębiorstwo społeczne. Kapitalizm dla ludzi, tłum. Z. Wiankowska-Ładyka, ConCorda, Warszawa.

Żwawa A. (2008), Ekonomia alternatywna-obecność idei w Polsce, eksperymenty, wnioski, które z nich wynikaja, oraz omówienie potencjalnych szans na rozwój tej ekonomii, „Ekonomia Społeczna Teksty", 2, http://www.es.teksty.ekonomiaspoleczna.pl/pdf/2008_2_ es_teksty.pdf [dostęp: 6.10.2017]. 